\title{
The biogeochemistry of precious metals; in memorium of Frank Reith
}

\author{
FRANK REITH $^{1,2}$, JEREMIAH SHUSTER ${ }^{1}$, G. SOUTHAM ${ }^{2}$ \\ ${ }^{1}$ School of Biological Sciences, The University of Adelaide, \\ Adelaide, SA 5005 Australia. \\ ${ }^{2}$ School of Earth \& Environmental Sciences, The University \\ of Queensland, St. Lucia, QLD 4072 Australia
}

The first morphological evidence for bacterial involvement in placer gold formation [1] was extremely controversial, and recanted soon after [2]. However, concurrent work, examining the immobilization of gold by bacteria, supported a biogeochemical model for placer gold formation by linking bacteria to octahedral gold. With advances in materials characterization, this 'bacterioform' gold was determined to be a dissolution feature of placer gold and not an artifact of sample preparation, but unfortunately they are not bacteria. This is where Frank appeared on the scene, bringing molecular characterization to the placer gold literature, and identifying Cupriavidus metallidurans on gold grains (eventually on gold grains from all over the world). Today, it's not unusual to say that gold grains can 'grow' under surface conditions with the aid of bacteria. In a laboratory study, mm-scale gold grains were 'grown' from nanometre- to micrometre-scale gold particles (synthesized from range of biogeochemical laboratory models) with the surficial textures and morphologies of this 'synthetic' gold comparable to those found on placer gold. The structural, chemical and biological characterization of placer gold has provided an improved understanding of how biogeochemical processes contribute to the transformation of gold in nature. The biosphere drives the cycling of gold under surface to near-surface conditions with weathering contributing to the dispersal of fine-grained colloidal and octahedral gold. This finegrained gold provides a target and an opportunity, to track the dispersal of gold improving exploration.

[1] Watterson (1991) Geol. 20, 315-318.

[2] Watterson (1994) Geol. 22, 1144-1146. 